\title{
PRESERVING SENSE OF PLACE AT HISTORIC WATERFRONTS IN MALAYSIA
}

\author{
Badaruddin Mohamed ${ }^{1}$ and Nurbaidura Salim² \\ ${ }^{1}$ School of Housing, Building and Planning, Universiti Sains Malaysia, 11800 Penang \\ ${ }^{2}$ Sustainable Tourism Research Cluster, Universiti Sains Malaysia, 11800 Penang
}

\begin{abstract}
Historical preservation is important to protect significant historic resources from destruction and inappropriate changes. Urban waterfronts are unique cultural resources that have its own identity, represent the lifestyle of surrounding communities. Over the years, the activities along the waterfront have changed along with city development, resulting in the loss of sense of place. In recent years, the agenda of preservation the cultural value of waterfront areas has been a research focus among the civil society and NGOs. However, in the midst of rapid development, this aspect is often overlooked and deteriorates the historical values of the place. At the same time, the quality of life of waterfront communities is also affected. This conceptual paper is a call for a set of actions to ensure that historical values at these places are protected. Through content analysis from previous literature reviews, this paper investigates how regeneration of historic waterfronts can help in preserving sense of place and improve the quality of life among waterfront communities. Findings from the literature revealed that contextual integration is important for successful redevelopment of historic waterfronts in order to preserve their sense of place.
\end{abstract}

\section{Introduction}

The place identity expresses a harmonious balance between people and urban events that are linked to one another, making a place unique and attached to the people [1]. At the same time, these places are moving forward with the rapid development and globalization, contributing to the change of places in urban areas. This situation has resulted to the increasing urban identity crisis, where cities, places, customs and behavourial patterns resemble to one another (Bentley in Sepe, 2013). De-territorialisation of waterfront areas due to globalization and commercialization is a common trend, place identity at the waterfront areas slowly deteriorate. Abandonment of waterfront due to globalization and technology changes has been a focus of research in recent years. As a result, urban waterfront has become derelict, loss sense of place and eventually the community has turned its back. This situation can be seen in many waterfront cities in Malaysia. Kangar Waterfront is one fine example of this situation. Located at the center of Perlis and among recreation nodes of Perlis River, research conducted by Abu Bakar, Ujang [2] revealed that the waterfront fail to function as social and recreational public place due to its degrading condition. Poor water quality, erosion, flooding, vandalism and pollution are some the issues observed at the waterfront, and eventually affected the way community use and engage with the waterfront.

Another good example can be derived from the Clan Jetties in Penang. Although the Clan Jetties is considered as 'living heritage' by the Penang State Government, tourist arrivals seem to be flocked at the clan village. From the positive sides, the local people perceived this scenario as money-oriented business and lucrative source of income to serve tourists' needs. While at the same time, the identity of the place may be deteriorated and forgotten if awareness to preserve sense of place and place identity are not emphasize. Some scholars argued that the loss of sense of place and its meaning contributed to negative impacts, not only to the individuals but also community identity [3]. Although today the Clan Jetty is still home to many people living in this area, many have changed their social and cultural historic. 
Realizing that historic waterfront a have strong and unique contribution to the history of Penang, current research suggests the needs to preserve its social and cultural history [4]. This paper will adopt phenomenological reading for urban waterfront areas and suggest factors contributing to sense of place at waterfront areas. In order to achieve this aim, this paper will define the concept of sense of place, its importance and relationship to historic preservation, communities and culture of places.

\section{Creating A Sense of Place}

Due to its interdisciplinary nature, there is a lack of understanding of 'sense of place'. Although there is unclear definition of this concept, most scholars agree that the 'sense of place' are likely related to: (1) emotional attachment of a place, and (2) interpretive perspective on places [4]. It a multidimensional concept that defines identity (relationship between people and place), attachment (emotional relationship to the place) and dependence (degree to which the place is believed to strengthen behaviour) [5]. Based on the understanding of these definitions, it can be described that physical environment plays an important role in reflecting the identity of its users. While the places influence self-identity, people tend to learn, understand, create and maintain their physical surroundings which reflect themselves. A sense of place is a combination of characteristics that makes a place unique and special. Steel in Hussain, Mohd Yunos [6] suggested three main attributes to shape the sense of place, which includes physical setting, social activities, meaning and image.

In understanding characteristics of a place, studies by previous scholars revealed the importance of attributes that create the sense of place. A sense of place is about creating a place to become unique and special for local community as well as visitors. It should be based on the understanding of cultural identity, social activity, physical environment and heritage of a place. A strong sense of place is a place where people would like to be part of and feel connected to the place. One of the key attributes of a successful place is the ability of the place to encourage social interaction among people. It provides people with a sense of belonging to the environment.

In recent years, the role of cultural and history has become a driving factor in the process of waterfront regeneration. According to Shamsuddin, Sulaiman [7], historic waterfronts are usually redeveloped as maritime conservation and reuse of adaptive heritage buildings. Such development is believed to boost economic to municipalities, help in revitalise the areas and enhance local businesses. Historic preservation commences when people value their heritage. Historic preservation not only adds values to the host communities and visitors, but also provides opportunity for future generations to learn and appreciate the legacy of previous history. Based on the final report of 2003 Michigan Land Use Leadership Council (MLULC), a sense of place can be created with collaborations between government and private sectors, working together to create and maintain liveable urban areas. 'Liveable' urban areas in this context, emphasize on the places where people meet, live, work, shop, invest and grow a business, learn and recreate. In order to achieve liveable urban areas, developing 'green infrastructure' within core urban areas is encouraged. In this context, waterfront redevelopment should have consider development that related to heritage, local people, cultural, recreational, commercial, educational and environment waterfront [7].

One of the examples to create a strong sense of place at waterfront areas is to implement adaptive reuse concept of the surrounding historic buildings. Besides that, community involvement is also important to create a strong place identity so that stakeholders can identify their specific needs and concerns. The means of engaging public participation is to achieve ongoing feedbacks and creative solutions to the recurring problems.

The use of waterfront vacant infrastructures by cultural artists can create a new and different appreciation of the built environment, creating a new product for cultural consumption. For example, the initiative taken by Penang State Government, Malaysia to introduce Penang Street Art around the Georgetown city has rejuvenated the living heritage within the World Heritage City. The 'Marking Georgetown' initiative intended to explore the ideas in art for public spaces in the city. More than 50 arts made from iron wrought sculptures were erected on the selected city's building walls. These arts indirectly help the tourists to understand and see the happenings, culture and how things were decades ago. These street arts also have attracted many tourists to visit the Heritage City for the past few years. Besides help to educate the tourists on the local culture, they also may enjoy to snap pictures with mural. All paintings and street arts at the selected walls tell its own story of the previous local daily routine. There were some of the culture and routine that is still being practice until today. For instance, the most painting in Georgetown World Heritage City 
is the 'Two Children on A Bicycle' which located at Armenian Street. The painting depicted the time when bicycle was the main mode of transportation in Georgetown (Figure 2.3). Another well known street art is 'Jimmy Choo' at Lebuh Leith where this is the place where the famous designer started his shoes apprenticeship (Figure 2.1).
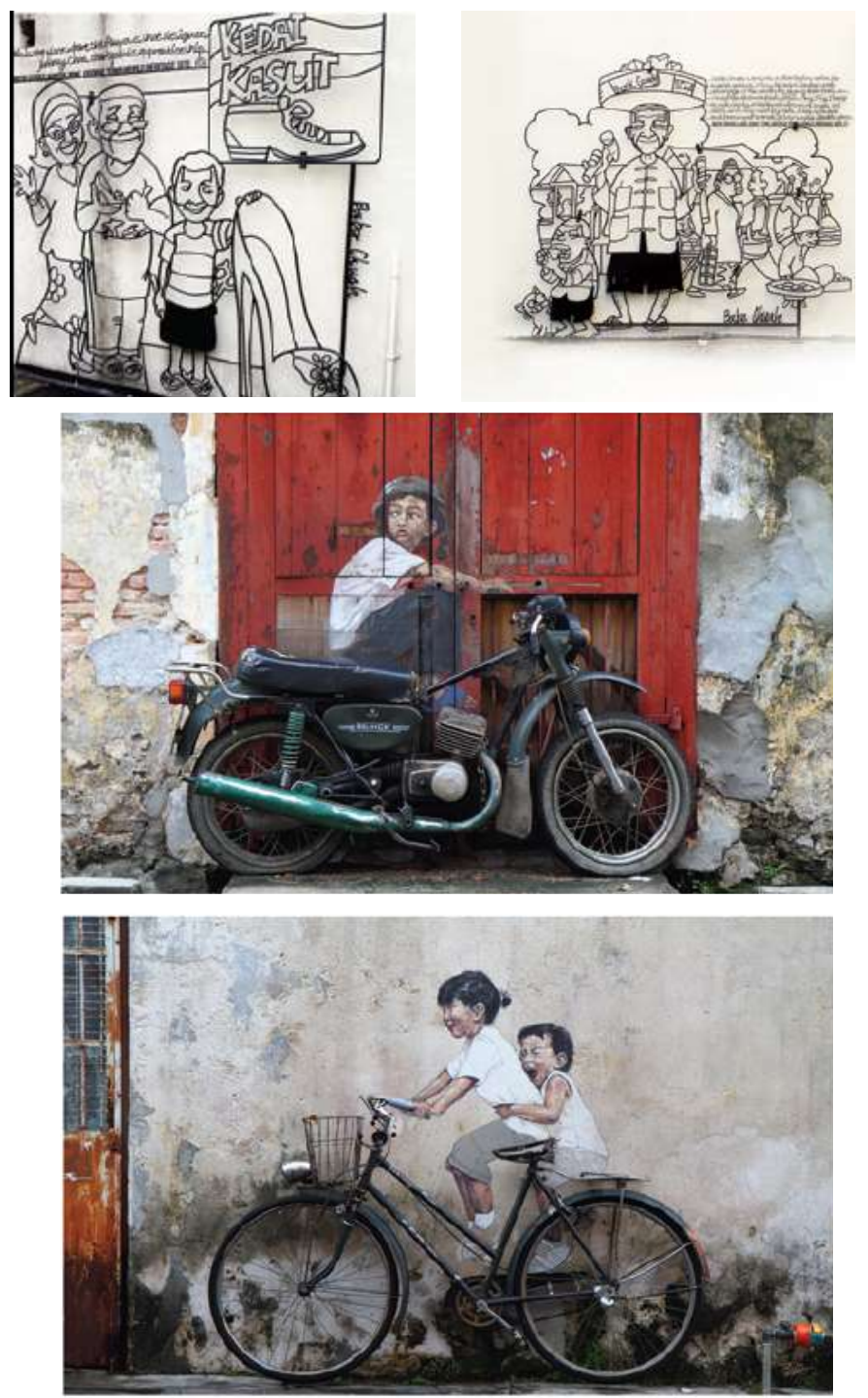


\section{Research Methodology}

This research will consider Georgetown Waterfront, Penang as a study area, which covers areas from the Clan Jetties to Fort Cornwallis. Georgetown Waterfront is chosen as my study area due to the rapid changes experienced by waterfront and its surrounding areas. With recognition as a 'World Heritage Site' (WHS) by UNESCO in 7 July 2008 , tourism development in Penang has rocketed and improve the economic development of city.

This study will employ qualitative approach by using extensive reviews of urban planning documents in Special Area Plan of Georgetown, Penang. According to Conzen [8], analysis of morphology can be described in three stages which include surveying, mapping and analytical techniques. Xie and Gu [9] employed this method in their research of waterfront revitalization in New Zealand. In this research, data collection will be conducted in three stages. Early phase of data collection will involve a review of governmental documents which includes National Physical Plan, Penang Local Plan, Special Area Plan of Georgetown and base maps of the study area. The documents outlining waterfront development plan will be compared with the actual historic-morphological shifts experienced by the waterfront in recent decades. The documents include the publication by the Penang City Council (Majlis Bandaraya Pulau Pinang), Special Area Plan of Georgetown established in 2016 to study the revitalization of the waterfront near the city centre. In addition, Penang Local Plan will also be referred to oversee the study the direction of long term development strategies. Historical documents about Georgetown will be examined to understand the morphological patterns of Georgetown Waterfront.

The second stage of this research will record any changes in urban tourism planning on streets and buildings adjacent to the waterfront area. At this stage, direct observation will be employed. The research will adopt a phenomenological approach as a method of study. Subsequently, the phenomenological approach in this research would be reading and observe the place, derived from Francis Violich's phenomenological reading. An inventory consists of building use will be recorded and plotted to identify variation of urban forms. The inventory tools will also assess past and present use of the heritage buildings at the study area. This process is important to evaluate how changes in tourism development have affected the facade and use of the adjacent buildings. In order to support the data, an in-depth interview with the Penang City Council, PLANMalaysia@Penang (formerly known as Penang Town and Country Planning Department) and local community will be held to identify further information pertaining to conservation, tourism and revitalization issues at the study area.

\section{Conclusion}

The purpose of this paper is to investigate the importance of sense of place at historic waterfronts. Preservation of historic buildings and adaptive use of old buildings can help in creating sense of place. At the same time, preserve the local identity at the waterfront. Participation from local people is important since they are the ones that have close attachment to the waterfront. Smart land use planning and community development initiative can help in recreating a sense of place at waterfront areas.

\section{Acknowledgement}

The funding for this project was made possible through the research grant obtained from the Ministry of Higher Education, Malaysia under the Transdisciplinary Research Grant Scheme 2016 [TRGS grant no: 203.PPBGN.67611002].

\section{References}

1. Sepe, M., Planning and Place in the City: Mapping Place Identity. 2013: Taylor \& Francis.

2. Abu Bakar, E.A., N. Ujang, and F. Abdul Aziz, PLACE ATTACHMENT TOWARDS WATERFRONT IN KANGAR, PERLIS, MALAYSIA. Alam Cipta, 2016. 9(2): p. 33-44. 
3. Karsono, B., D. Deni, and C.A. Fithri, Assessment of Functional and Emotional Attachment in Malacca Riverfront Promenade. Jurnal Teknologi, 2016. 1(1).

4. Ng, V., Toward A Holistic Understanding of Sense of Place: A Phenomenological Reading of Chew Jetty, Penang. International Journal of Humanities and Social Science, 2013. 3(20): p. 75-83.

5. Jorgensen, B.S. and R.C. Stedman, SENSE OF PLACE AS AN ATTITUDE: LAKESHORE OWNERS ATTITUDES TOWARD THEIR PROPERTIES. Journal of Environmental Psychology, 2001. 21(3): p. 233-248.

6. Hussain, M.A., et al., Interaction on Impression of Place at Historic Waterfront. RESEARCH JOURNAL OF FISHERIES AND HYDROBIOLOG, 2015. 10(4): p. 112-114.

7. Shamsuddin, S., et al., Regeneration of the Historica Waterfront of World Heritage Sites in Malaysia: The case of Georgetown and Melaka, in UK Ireland Planning Research Conference. 2010: United Kingdom.

8. Conzen, M.R.G., Alnwick, Northumberland: A Study in Town-plan Analysis. 1969: Institute of British Geographers.

9. Xie, P.F. and K. Gu, The changing urban morphology: Waterfront redevelopment and event tourism in New Zealand. Tourism Management Perspectives, 2015. 15: p. 105-114. 